\title{
Species Composition of Tropical Understory Birds in Threatened East African Coastal Forests Based on Capture Data
}

\author{
Robert B. Modest and Shombe N. Hassan \\ Department of Wildlife Management, Sokoine University of Agriculture, P.O. Box 3073, Morogoro, Tanzania \\ Correspondence should be addressed to Robert B. Modest; robertbya@yahoo.com
}

Received 10 December 2015; Revised 17 February 2016; Accepted 3 March 2016

Academic Editor: Eugene S. Morton

Copyright (C) 2016 R. B. Modest and S. N. Hassan. This is an open access article distributed under the Creative Commons Attribution License, which permits unrestricted use, distribution, and reproduction in any medium, provided the original work is properly cited.

\begin{abstract}
The East African coastal forests are subject of haphazard modification following anthropogenic pressures including tree cutting and clearing for agriculture. These activities, which are leading cause of habitat disturbance and species loss, are the major challenge in the management of sensitive wildlife species such as forest understory birds. This study investigated species composition of understory birds in the coastal forests of northeastern Tanzania to generate information for the management of the landscape and biodiversity in the area. Using mist nets, birds were trapped from core and edge habitats of representative forest patches. Trapped birds were classified to species level and categorized into bird guilds based on their levels of forest dependence. It was found out that species richness was influenced by forest patch size rather than level of habitat disturbance. Edge habitat was also found to be important in hosting higher number of forest understory birds, especially generalists—but this should be treated with caution because following habitat destruction that is ongoing in the study area, there is a danger of generalist wiping out specialist species due to competitive exclusion. Strict control measures to stop illegal tree cutting and agricultural activities near the forests were recommended for sustainable conservation of the understory birds in the forests.
\end{abstract}

\section{Introduction}

On telling the status and complexity of forest ecosystems, understory bird species composition is of particular consideration [1-3]. The role of understory birds in shaping the forests ranges from seed dispersal $[4,5]$ to pollination as well as pest control [6], among others. However, persistence of most species of this ecological guild within forested habitat is determined by many factors, such as canopy cover and vegetation stratification [7-9], and microclimatic conditions [1012]. Unfortunately, in most of tropical landscapes, these vital factors which define forest structures are subject of haphazard modification following human actions such as man-made fires and unsustainable use of the forest resources-with ultimate negative consequences on bird diversity [11, 13-16]. Under this scenario, the role of understory birds in particular frugivores is indispensable mainly on dispersal of seeds to fill gaps that are left behind after negative anthropogenic activities including uncontrolled harvest of forest flora-the process which helps in ecological succession and recovery of habitats $[4,5]$. An additional, yet important role of forest understory birds can be noted within the agriculture sector, whereby loss or decline of understory insectivores owing to habitat degradation, for example, has obvious implications including crop loss as a result of increased abundance in invertebrate pests $[1,6]$.

The East African coastal forests are reknown for their high bird diversity and endemism $[17,18]$. However, these forests face uncontrolled human livelihood issues that include tree cutting, charcoal burning, and habitat clearing for agriculture $[15,17,19]$. These deleterious activities lead to habitat disturbance and fragmentation with eventual negative consequences on bird populations $[4,18]$. Previous researches within the forests such as that of Hassan et al. [15] based on point count and that of Korfanta et al. [2] as well as Newmark [1] based on mist netting reported that deleterious anthropogenic activities were the major reason for the uneven distribution of avifauna species among the forests. 
The current study focused on the coastal forests of the Saadani National Park, but the study extended beyond the park boundary to include two forest reserves in the northern part, namely, Msubugwe and Gendagenda. The vegetation of the Saadani National Park and neighboring landscape portray varied levels of ecosystem succession following the differential shifts in previous land use regimes. The land use systems the park has gone through before being gazetted into a national park include being managed as a cattle ranch and sisal plantation $[20,21]$ and the ongoing fishery along the Indian Ocean shoreline. Indeed, the repercussion brought about by the former two land use regimes on bird species composition could be enormous, including negatively impacting species richness or causing local extinction in some of the species, for example.

There are insufficient efforts dedicated on collecting ornithological information in the coastal forests of the Saadani National Park and its surrounding environs. The few attempts include the exploratory study by Burgess et al. [22], a study on bird breeding biology by Mlingwa [23], and an investigation on influence of forest disturbance on forest birds by Hassan et al. [15]. A more recent study by Modest et al. [19] examined effects of forest patch size on specialist and generalist birds. This narrative thus reveals a gap pertaining to information on understory bird species composition. Yet, this information is crucial for the government of Tanzania and conservationists in understanding the welfare of the indicators of forest health (i.e., the forest understory birds), especially within the valued but highly threatened landscapes such as the East African coastal forests. The aim of this study therefore was to determine factors underpinning species assemblage of understory birds among forest fragments of the threatened biodiversity hotspot in the northeastern part of Tanzania. It is anticipated that the information gathered will have implications in planning management options for the recovery and sustainability of the biodiversity of the forests.

\section{Material and Methods}

2.1. Study Area. The data was collected from four forest patches, namely, Zaraninge $\left(42.7 \mathrm{~km}^{2}\right)$, Kwamsisi $\left(4.06 \mathrm{~km}^{2}\right)$, Gendagenda $\left(10.97 \mathrm{~km}^{2}\right)$, and Msubugwe $\left(22.32 \mathrm{~km}^{2}\right)$. The first two forests are found in Saadani National Park (SANAPA), while the other two are located about $10 \mathrm{~km}$ north of SANAPA and have forest reserve statuses. These forests show different levels of habitat disturbance with Msubugwe being highly disturbed. The Zaraninge, Kwamsisi, and Gendagenda forests however are in a relatively undisturbed state [15]. The geographical location of the study site is between $6^{\circ} 16^{\prime} 42.94^{\prime \prime}$ and $6^{\circ} 16^{\prime} 57.65^{\prime \prime} \mathrm{S}$ and $38^{\circ} 32^{\prime} 08.35^{\prime \prime}$ and $38^{\circ} 51^{\prime} 17.37^{\prime \prime} \mathrm{E}$ (Figure 1). There are two rainy seasons: the short rains being from October to December and the long rains from March to May [19, 20]. Furthermore, the area is rich in endemism with a number of East African endemic species represented there, including the Sokoke pipit Anthus sokokensis, little yellow flycatcher Erythrocercus holochlorus, Fischer's greenbul Phyllastrephus fischeri, Kretschmer's longbill Macrosphenus kretschmeri, and plain-backed sunbird Anthreptes reichenowi [17].

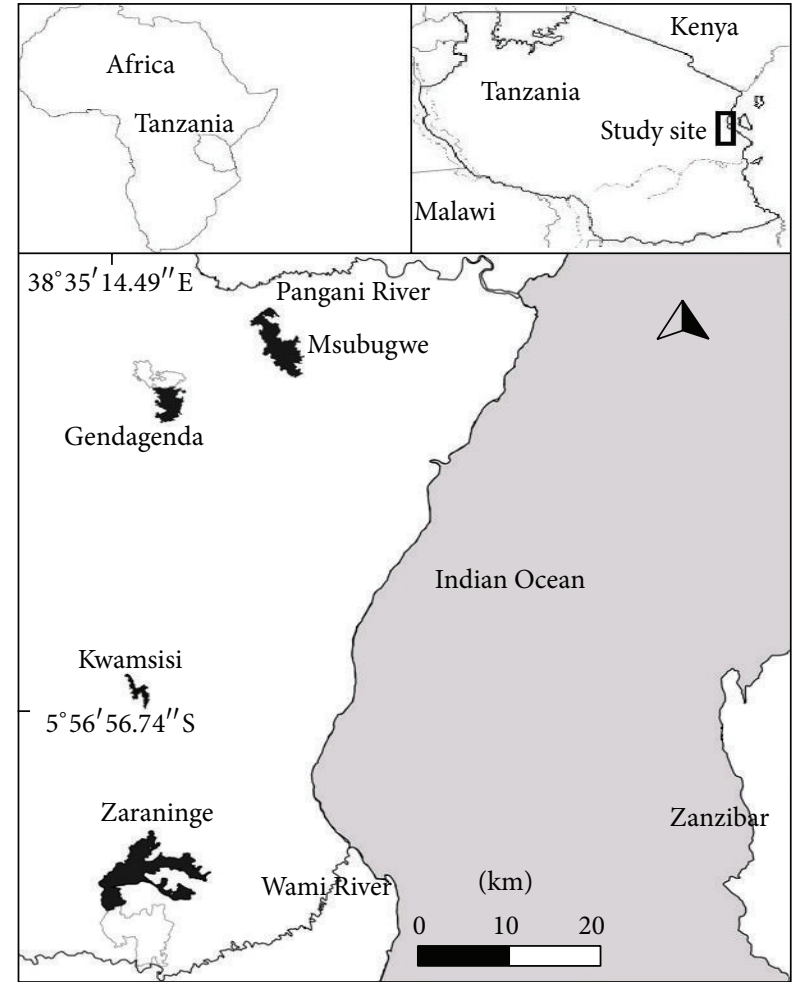

FIGURE 1: Map of the study area. Black polygons indicate study forests. Source: modified after Modest et al. [19].

2.2. Bird Trapping. Between October 2010 and August 2012 birds were trapped from 17 mist net sites distributed in the four forests mentioned above. Allocation of mist net sites was biased such that Zaraninge, which is the biggest of the study forests, had six sites. The number of mist net sites in the rest of the forests was as follows: Msubugwe (five), Gendagenda (four), and Kwamsisi (two). This design allowed us to dedicate more efforts in bigger forests to allow for exhaustive sampling. Nets in the edge habitat were fixed about $10 \mathrm{~m}$ inside the forests regardless of the characteristic of the neighboring landscapes-whether agricultural field or savannah/woodland. Since the cross-sectional distance for the Kwamsisi forest was the least (about a kilometer), in all the forests core habitats were considered as areas about $500 \mathrm{~m}$ from the edge.

Positioning of the first mist net site in core and edge habitat of each of the forests was purposefully decided based on suitability of the site, but locations for the subsequent sites were determined systematically at an interdistance of $250 \mathrm{~m}$. An interdistance of $250 \mathrm{~m}$ was chosen largely to minimize walking time between sites. The mist net sites were distributed equally between core and edge habitat except in Msubugwe where an extra site was located in the core habitat next to a road that traverses the forest. At each site, six mist nets of $12 \mathrm{~m}$ by $3.2 \mathrm{~m}$ with $14 \mathrm{~mm}$ ( 3 nets) and $20 \mathrm{~mm}$ (3 nets) mesh sizes were fixed for trapping birds. Trapping was done once monthly per site and nets were opened from $6.00 \mathrm{a}$ a.m. to 10.00 a.m. Trapping exercise was carried out in the morning only so as to avoid stressing the birds as the East African 
TABle 1: Percentage of distribution of bird guilds among forest patches. Bird guilds are indicated according to level of forest dependence as $\mathrm{FF}=$ forest specialist, $\mathrm{F}=$ forest generalist, $\mathrm{f}=$ forest visitor, and $\mathrm{s}=$ woodland/savannah species.

\begin{tabular}{lcccc}
\hline SITE & FF & F & f & s \\
\hline Gendagenda & 25.71 & 31.25 & 39.13 & 62.5 \\
Kwamsisi & 20.00 & 21.88 & 17.39 & 6.25 \\
Msubugwe & 20.00 & 21.88 & 26.09 & 0.00 \\
Zaraninge & 34.29 & 25.00 & 17.39 & 31.25 \\
Total & $\mathbf{1 0 0}$ & $\mathbf{1 0 0}$ & $\mathbf{1 0 0}$ & $\mathbf{1 0 0}$ \\
\hline
\end{tabular}

coastal forests usually experience high temperatures during day time $[24,25]$. Upon capture, birds were banded with colour rings for easy recognition when retrapped. The birds were then identified to species level and released at the same trapping spot. Individuals were only recorded on first capture whereas recaptures were excluded from further analysis to avoid estimation bias [26, 27].

2.3. Statistical Analyses. Taxonomical bird classification was accomplished using the databases by Gill and Donsker [28] and Clements et al. [29], whereby species were assigned to respective orders and families. Birds were also categorized into guilds based on their degree of forest dependence as FF, forest specialist, $F$, forests generalist, $\mathrm{f}$, forest visitor, and s, savannah/woodland species. The classification followed Bennun et al. [30], and where a species was not present in their list, Hassan et al. [15], Mlamba et al. [31], or Owino et al. [32] were opted for. Four species were not found in any of these references, namely, African cuckoo, Basra reed warbler, marsh warbler, and pied kingfisher. These were classified using the procedure presented in Bennun et al. [30] with reference notes from Stevenson and Fanshawe [33]. Furthermore, three species, namely, African goshawk, little sparrowhawk, and African wood owl, were removed from further analysis to avoid biasing the results as these bigger sized individuals were considered to have been caught by the small-mesh mist nets just by chance [27].

We computed Shannon Diversity Indices $\left(H^{\prime}\right)$ for the individuals trapped from each of the sampling sites using the equation $H^{\prime}=-\sum P_{i}\left(\ln P_{i}\right)$, where $P_{i}$ is the proportion of each species in the sample. The Shannon Diversity Indices were then used to fit a generalized linear mixed-effects model in the R program using package lme4 [34] to determine habitat features that are important in influencing species diversity. On fitting this model, three covariates were used, namely, forest size, habitat type (categorized as core or edge), and disturbance level (categorized as disturbed or undisturbed). The Shannon Diversity Index was used as response variable and disturbance as the random effect, whereas forest size and habitat type were used as the fixed effects.

We used Mann-Whitney $U$-statistic test to determine significant difference in assemblage of all bird species between core and edge habitats. The same test was also used to determine significant difference in the number of forest generalist birds between core and edge habitats.
TABLE 2: Generalized linear mixed-effects model on association of the Shannon-Weiner Diversity Indices with forest size and habitat type. Habitat was entered in the model as core or edge, whereby "edge" was retained by the model along with "forest size" as important covariates in influencing understory birds.

\begin{tabular}{lcccc}
\hline Covariate & Value & Std. error & LCI & UCI \\
\hline Intercept & 1.966 & 0.154 & 1.633 & 2.299 \\
Forest size & 0.003 & 0.006 & -0.010 & 0.016 \\
Habitat_"edge” & 0.066 & 0.177 & -0.317 & 0.449 \\
\hline
\end{tabular}

To visualize trend of relationship between forest size and total number of species recorded in each forest, a bar chart with standard errors was plotted. Moreover, the individuals captured from each forest were used to calculate estimated species richness S(est) using EstimateS 9.1.0 software [35]. The same software was also used to calculate the MorisitaHorn Sample Similarity Indices. To compare observed and estimated species richness among forests, the rarefaction and extrapolation curves of S(est) along with their 95\% CI were also computed $[27,36]$.

\section{Results}

Five hundred and seventy-seven (577) individuals belonging to 57 species and making 27 families were trapped. Of the 57 species recorded, 13 species were forest specialists (FF), 15 forest generalists (F), 14 forest visitors (f), and 15 savannah/woodland species (s) (refer to Table 3). Table 1 shows distribution of bird guilds among the forest patches. The Zaraninge forest had more proportion of forest specialist species while Gendagenda had more proportions of forest visitors and woodland/savannah species. The Msubugwe forest on the other hand did not have any of the woodland/savannah species represented.

The generalized linear mixed-effects model retained two covariates, namely, "forest size" and "edge habitat." This signifies that, among those covariates entered into the global model, these two were the most important in influencing bird diversity (Table 2).

While there were more generalist than specialist birds in edge habitats (means, $\mathrm{F}=9.16 \pm 1.78 \mathrm{SE}, \mathrm{FF}=4.59 \pm$ $0.83 \mathrm{SE}$, Mann-Whitney $U$-statistic $=133.00$, and $p=0.04$ ), the number of individuals making the four categorized bird guilds did not differ significantly between core and edge habitats (means, core $=5.02 \pm 0.68 \mathrm{SE}$, edge $=5.5 \pm$ 0.70 SE, Mann-Whitney $U$-statistic $=1403.50$, and $p=0.92$ ). However, the total number of species recorded from each of the four forests showed a decreasing trend relative to forest size (Figure 2).

The estimated understory bird species richness $\mathrm{S}$ (est) was as follows: Kwamsisi 26.50 (95\% CI 20.05; 32.92), Gendagenda 38.17 (95\% CI 30.64; 45.69), Msubugwe 47.25 (95\% CI 38.68; 55.82), and Zaraninge 55 (95\% CI 45.25; 64.75). Furthermore, the Morisita-Horn Sample Similarity Indices between forests were as follows: Gendagenda/Kwamsisi 0.72 , Gendagenda/Msubugwe 0.62, Gendagenda/Zaraninge 0.65, Kwamsisi/Msubugwe 0.64, Kwamsisi/Zaraninge 0.61, 
TABLE 3: List of species captured during mist netting in Saadani National Park and surrounding areas. The last four columns show record of individual species per forest, whereby rows with zero (0) values mean no record, while values of ones (1s) show that at least one individual of that particular species was recorded. GLD = guild, $\mathrm{SPP}$. REC/FOR = species record per forest, $\mathrm{Z}=\mathrm{Zaraninge}, \mathrm{K}=\mathrm{Kwamsisi}$, $\mathrm{G}=\mathrm{Gendagenda}$, $\mathrm{M}=$ Msubugwe, $\mathrm{FF}=$ forest specialist, $\mathrm{F}=$ forest generalist, $\mathrm{f}=$ forest visitor, and $\mathrm{s}=$ woodland $/$ savannah species.

\begin{tabular}{|c|c|c|c|c|c|c|c|c|}
\hline \multirow{2}{*}{ English name } & \multirow{2}{*}{ Scientific name } & \multirow{2}{*}{ Order } & \multirow{2}{*}{ Family } & \multirow{2}{*}{ GLD } & \multicolumn{4}{|c|}{ SPP. REC/FOR } \\
\hline & & & & & $\mathrm{Z}$ & $\mathrm{K}$ & G & M \\
\hline African broadbill & Smithornis capensis & Passeriformes & Eurylaimidae & $\mathrm{FF}$ & 1 & 1 & 0 & 0 \\
\hline African cuckoo & Cuculus gularis & Cuculiformes & Cuculidae & $\mathrm{s}$ & 0 & 0 & 1 & 0 \\
\hline African goshawk & Accipiter tachiro & Accipitriformes & Accipitridae & $\mathrm{F}$ & 1 & 0 & 0 & 0 \\
\hline African paradise flycatcher & Terpsiphone viridis & Passeriformes & Monarchidae & $\mathrm{F}$ & 1 & 1 & 0 & 0 \\
\hline African pygmy kingfisher & Ispidina picta & Coraciiformes & Alcedinidae & $\mathrm{f}$ & 1 & 0 & 0 & 0 \\
\hline Ashy flycatcher & Muscicapa caerulescens & Passeriformes & Muscicapidae & $\mathrm{F}$ & 1 & 0 & 0 & 1 \\
\hline Basra reed warbler & Acrocephalus griseldis & Passeriformes & Acrocephalidae & $\mathrm{s}$ & 0 & 0 & 1 & 0 \\
\hline Bearded scrub robin & Cercotrichas quadrivirgata & Passeriformes & Muscicapidae & $\mathrm{f}$ & 1 & 1 & 0 & 1 \\
\hline Black-backed puffback & Dryoscopus cubla & Passeriformes & Malaconotidae & $\mathrm{F}$ & 1 & 1 & 0 & 1 \\
\hline Blue-mantled crested flycatcher & r Trochocercus cyanomelas & Passeriformes & Monarchidae & $\mathrm{FF}$ & 1 & 1 & 0 & 1 \\
\hline Brown-hooded kingfisher & Halcyon albiventris & Coraciiformes & Alcedinidae & s & 0 & 0 & 1 & 0 \\
\hline Collared sunbird & Hedydipna collaris & Passeriformes & Nectariniidae & $\mathrm{F}$ & 1 & 1 & 0 & 0 \\
\hline Common bulbul & Pycnonotus barbatus & Passeriformes & Pycnonotidae & $\mathrm{F}$ & 1 & 1 & 0 & 0 \\
\hline Common cuckoo & Cuculus canorus & Cuculiformes & Cuculidae & $\mathrm{s}$ & 1 & 0 & 0 & 0 \\
\hline Dark-backed weaver & Ploceus bicolor & Passeriformes & Ploceidae & $\mathrm{F}$ & 1 & 0 & 0 & 0 \\
\hline Eastern nicator & Nicator gularis & Passeriformes & Nicatoridae & $\mathrm{F}$ & 1 & 1 & 1 & 1 \\
\hline Fischer's greenbul & Phyllastrephus fischeri & Passeriformes & Pycnonotidae & FF & 1 & 0 & 0 & 1 \\
\hline Forest batis & Batis mixta & Passeriformes & Platysteiridae & FF & 1 & 1 & 1 & 1 \\
\hline Garden warbler & Sylvia borin & Passeriformes & Sylviidae & $\mathrm{f}$ & 0 & 0 & 1 & 0 \\
\hline Golden-breasted starling & Lamprotornis regius & Passeriformes & Sturnidae & s & 1 & 0 & 0 & 0 \\
\hline Green wood hoopoe & Phoeniculus purpureus & Bucerotiformes & Phoeniculidae & $\mathrm{s}$ & 0 & 0 & 0 & 1 \\
\hline Green-backed twinspot & Mandingoa nitidula & Passeriformes & Estrildidae & $\mathrm{FF}$ & 1 & 1 & 0 & 0 \\
\hline Green-backed woodpecker & Campethera cailliautii & Piciformes & Picidae & $\mathrm{f}$ & 0 & 0 & 0 & 1 \\
\hline Green-winged pytilia & Pytilia melba & Passeriformes & Estrildidae & s & 0 & 0 & 1 & 0 \\
\hline Grey-backed camaroptera & Camaroptera brachyura & Passeriformes & Cisticolidae & $\mathrm{f}$ & 1 & 1 & 0 & 1 \\
\hline Holub's golden weaver & Ploceus xanthops & Passeriformes & Ploceidae & $\mathrm{s}$ & 0 & 0 & 1 & 0 \\
\hline Kretschmer's longbill & Macrosphenus kretschmeri & Passeriformes & Macrosphenidae & FF & 1 & 0 & 0 & 0 \\
\hline Lesser cuckoo & Cuculus poliocephalus & Cuculiformes & Cuculidae & $\mathrm{f}$ & 0 & 0 & 1 & 0 \\
\hline Little sparrowhawk & Accipiter minullus & Accipitriformes & Accipitridae & $\mathrm{f}$ & 1 & 0 & 0 & 0 \\
\hline Lowland tiny greenbul & Phyllastrephus debilis & Passeriformes & Pycnonotidae & $\mathrm{FF}$ & 1 & 1 & 1 & 1 \\
\hline Marsh warbler & Acrocephalus palustris & Passeriformes & Acrocephalidae & $\mathrm{s}$ & 0 & 0 & 1 & 0 \\
\hline Narina trogon & Apaloderma narina & Trogoniformes & Trogonidae & $\mathrm{F}$ & 1 & 0 & 0 & 1 \\
\hline Northern brownbul & Phyllastrephus strepitans & Passeriformes & Pycnonotidae & $\mathrm{f}$ & 0 & 0 & 1 & 0 \\
\hline Olive sunbird & Cyanomitra olivacea & Passeriformes & Nectariniidae & $\mathrm{FF}$ & 1 & 0 & 1 & 1 \\
\hline Peters's twinspot & Hypargos niveoguttatus & Passeriformes & Estrildidae & $\mathrm{F}$ & 1 & 1 & 0 & 0 \\
\hline Pied kingfisher & Ceryle rudis & Coraciiformes & Alcedinidae & $\mathrm{s}$ & 1 & 0 & 0 & 0 \\
\hline Plain-backed sunbird & Anthreptes reichenowi & Passeriformes & Nectariniidae & FF & 1 & 0 & 0 & 1 \\
\hline Red-capped robin-chat & Cossypha natalensis & Passeriformes & Muscicapidae & $\mathrm{F}$ & 1 & 1 & 0 & 1 \\
\hline Red-faced cisticola & Cisticola erythrops & Passeriformes & Cisticolidae & $\mathrm{s}$ & 0 & 0 & 0 & 1 \\
\hline Red-tailed ant thrush & Neocossyphus rufus & Passeriformes & Turdidae & FF & 1 & 0 & 0 & 1 \\
\hline Sokoke pipit & Anthus sokokensis & Passeriformes & Motacillidae & FF & 1 & 0 & 0 & 1 \\
\hline Sombre greenbul & Andropadus importunus & Passeriformes & Pycnonotidae & s & 1 & 0 & 0 & 0 \\
\hline Square-tailed drongo & Dicrurus ludwigii & Passeriformes & Dicruridae & $\mathrm{F}$ & 1 & 0 & 0 & 1 \\
\hline Striped kingfisher & Halcyon chelicuti & Coraciiformes & Alcedinidae & s & 1 & 0 & 0 & 0 \\
\hline Tambourine dove & Turtur tympanistria & Columbiformes & Columbidae & $\mathrm{F}$ & 1 & 1 & 0 & 0 \\
\hline Tawny-flanked prinia & Prinia subflava & Passeriformes & Cisticolidae & $\mathrm{f}$ & 0 & 0 & 0 & 1 \\
\hline
\end{tabular}


TABLE 3: Continued.

\begin{tabular}{|c|c|c|c|c|c|c|c|c|}
\hline \multirow{2}{*}{ English name } & \multirow{2}{*}{ Scientific name } & \multirow{2}{*}{ Order } & \multirow{2}{*}{ Family } & \multirow{2}{*}{ GLD } & \multicolumn{4}{|c|}{ SPP. REC/FOR } \\
\hline & & & & & $\mathrm{Z}$ & K & G & M \\
\hline Terrestrial brownbul & Phyllastrephus terrestris & Passeriformes & Pycnonotidae & $\mathrm{F}$ & 0 & 0 & 1 & 1 \\
\hline Thrush nightingale & Luscinia luscinia & Passeriformes & Muscicapidae & $\mathrm{s}$ & 0 & 0 & 1 & 0 \\
\hline Tropical boubou & Laniarius major & Passeriformes & Malaconotidae & $\mathrm{f}$ & 0 & 0 & 0 & 1 \\
\hline Uluguru violet-backed sunbird & Anthreptes neglectus & Passeriformes & Nectariniidae & $\mathrm{FF}$ & 0 & 0 & 1 & 1 \\
\hline White-browed scrub robin & Cercotrichas leucophrys & Passeriformes & Muscicapidae & s & 1 & 0 & 0 & 1 \\
\hline White-starred robin & Pogonocichla stellata & Passeriformes & Muscicapidae & $\mathrm{F}$ & 0 & 1 & 0 & 0 \\
\hline White-throated bee-eater & Merops albicollis & Coraciiformes & Meropidae & $\mathrm{f}$ & 0 & 0 & 0 & 1 \\
\hline Yellow-bellied greenbul & Chlorocichla flaviventris & Passeriformes & Pycnonotidae & $\mathrm{F}$ & 1 & 1 & 1 & 1 \\
\hline Yellow-breasted apalis & Apalis flavida & Passeriformes & Cisticolidae & $\mathrm{f}$ & 0 & 0 & 1 & 0 \\
\hline Yellow-rumped tinkerbird & Pogoniulus bilineatus & Piciformes & Lybiidae & $\mathrm{F}$ & 1 & 0 & 0 & 1 \\
\hline Yellow-streaked greenbul & Phyllastrephus flavostriatus & Passeriformes & Pycnonotidae & FF & 1 & 1 & 1 & 1 \\
\hline \multicolumn{5}{|l|}{ Total number of species per forest } & 37 & 18 & 19 & 28 \\
\hline
\end{tabular}

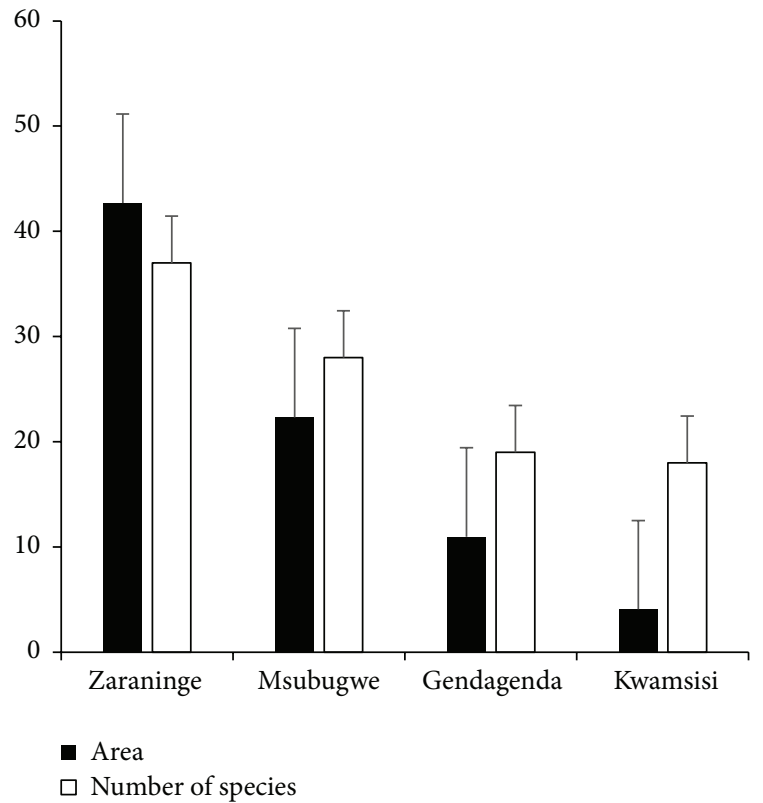

FIGURE 2: Comparison of total number of species recorded relative to forest area. The bars indicate standard errors.

and Msubugwe/Zaraninge 0.83 . The species rarefaction and extrapolation curve for the Kwamsisi forest plateaued. However, curves for the rest of the forests had positive slopes (Figure 3).

\section{Discussion}

Sampling of the forests was biased such that more efforts were dedicated to the bigger ones to ensure that the data collected is representative of the bird population relative to forest sizes. We recorded a total of 577 individuals of understory birds belonging to 57 species and 27 families. The number of individuals recorded was higher compared to 386 reported by Owino et al. [32] from 14 coastal forest patches along eastern Kenya. Due to the fact that our study covered only 4 forest patches, the higher number of individuals could be an indication that the coastal forests of northeastern Tanzania support higher abundance of understory birds compared to similar forests in neighboring countries.

Indeed, the two covariates, that is, "forest size" and "edge habitat," that were retained by the generalized linear mixed-effects model are important in the management of the understory bird species in the East African coastal forests of northeastern Tanzania. This is due to the fact that the confidence interval of the mixed-effects model intercept did not contain zero, suggesting that the two covariates are significant at the 5\% alpha of the model. The importance of forest edges on the understory birds as revealed by the model can be linked to forest generalist species particularly those that tend to use off forest habitat [37]. Thus, the fact that edge habitat was retained by the model signifies that most of the abundant species in particular forest generalists were trapped along forest edges, and this was reflected in the Shannon-Weiner Diversity Indices. The Mann-Whitney $U$-statistic test also confirms this as the difference between individuals of generalist species captured in edge and core habitats was extremely high (mean values, core $4.50 \pm 1.07 \mathrm{SE}$, edge $10.56 \pm 1.92 \mathrm{SE}$, Mann-Whitney $U$-statistic $=47.00$, and $p=0.007)$. Equally, the higher number of forest generalist species along edge habitats could be linked to agricultural activities that are undergoing in the neighborhoods of the forests. Agricultural activities tend to favour high bird diversity, especially nonforest species such as forest visitors and woodland/savannah species-mostly granivores and frugivores. For example, Buechley et al. [27] reported higher species richness in shade coffee farms compared to forest habitat, suggesting that agricultural modified habitat provides extra niches for species colonization. The current study also recorded the highest proportion of forest generalists, forest visitors, and woodland/savannah species in Gendagendathe forest patch which is highly affected by shifting cultivation. However, in Msubugwe, there were not any woodland/savannah species captured despite of the highest level of 

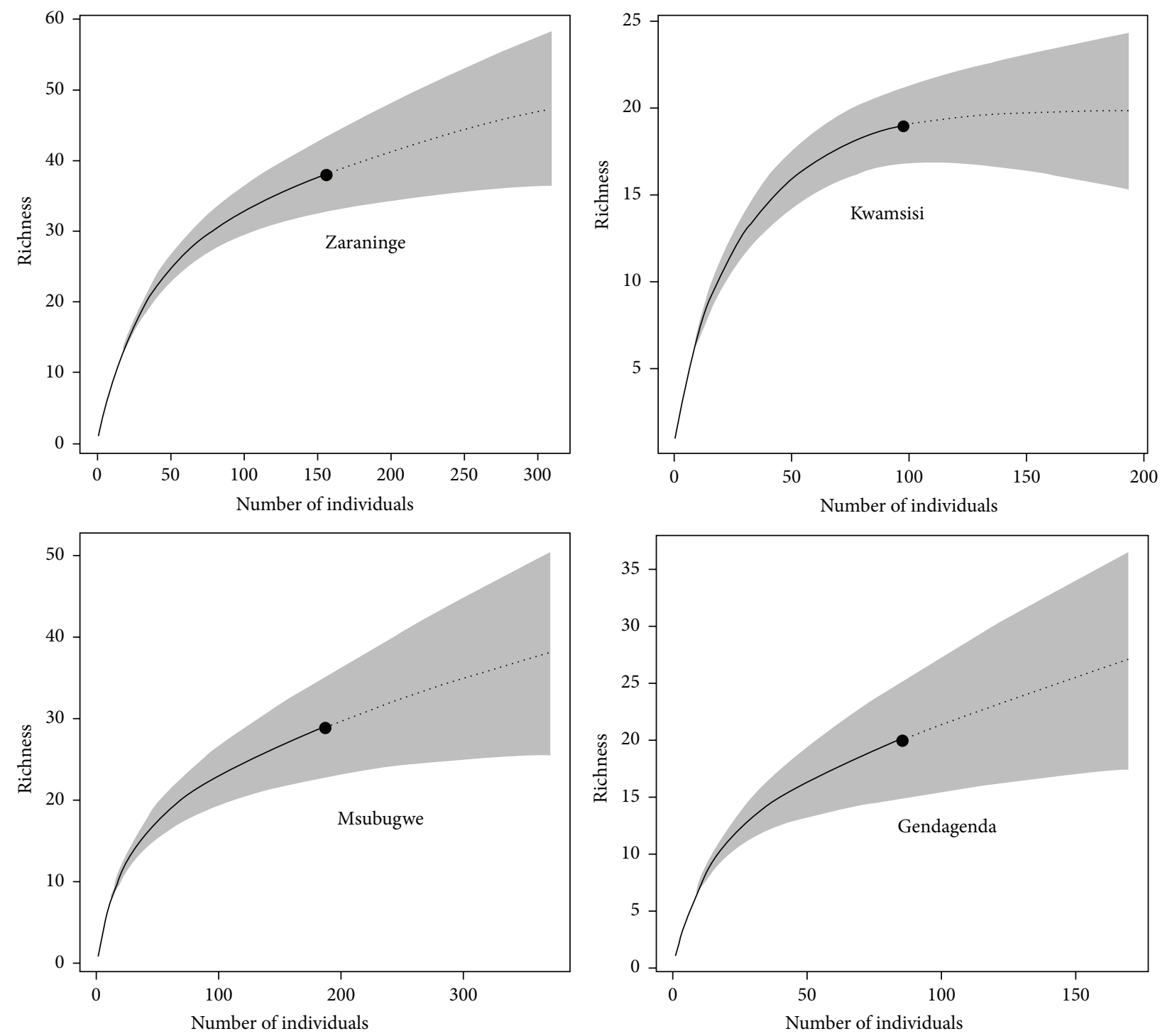

FIGURE 3: Species rarefaction and extrapolation curves of the four forests. Solid and dotted lines show rarefied and extrapolated richness, respectively. Shaded regions indicate $95 \%$ confidence intervals.

habitat degradation in this forest due to tree cutting. This is contrary to our expectation that habitat disturbance would have opened up more niches for the woodland/savannah species. Since there are no any agricultural activities ongoing in the neighborhood of the Msubugwe forest, the lack of the woodland/savannah species in this forest supports the argument above that practicing agriculture near protected forests paves way for exotic species such as woodland/savannah birds to access forested habitats. Indeed, as the sustainable management of the coastal forests of northeastern Tanzania is of great concern, this is alarming particularly if the bird species that are favoured include frugivores as there can be a risk of propagating exotic tree species with eventual competitive exclusion of the indigenous ones $[5,38]$.

The effect of forest size on birds and other taxa on the other hand has been documented widely, whereby species richness tends to increase as area increases; see, for example,
Uezu et al. [39], Watson et al. [8], and Martensen et al. [40]. For our study, this is evident in Figure 2, as the number of species recorded tended to decline as size of forest decreased. Therefore, following this scenario, it is obvious that the size of forests in the northeastern Tanzania region matters for the upkeep of understory birds and the biodiversity at large. For the persistence of understory birds and sustainable conservation of the East African coastal forests, however, it is important that the authorities responsible for the management of the forests should dedicate necessary efforts in controlling negative human pressures on the environment, especially stopping tree cutting and vegetation clearing for agriculture. If left uncontrolled, these activities are likely to cause unprecedented damage of the forests and the associated fauna in the near future-as their impact in reducing forest size and canopy cover is already evident (personal communication [15]). 
The estimated species richness S(est) and the MorisitaHorn Sample Similarity Index were the highest for the two bigger forests, namely, Msubugwe and Zaraninge, suggesting their high level of resemblance in bird communities. This is contrary to our expectations as these forests differ in their levels of habitat disturbance with Msubugwe being highly degraded compared to Zaraninge (see [15]). However, as pointed out above, it is likely that most of the species distribution among the forest patches within the East African coastal forests of northeastern Tanzania follows the area-species relationship, whereby bigger forest patches tend to host more species [8, 41]. Therefore, the higher S(est) and Morisita-Horn Sample Similarity Index of the Msubugwe/Zaraninge forests could be linked to their size as these two are the biggest among the forests studied. These findings also confirm results of the previous research done in the same region which revealed an area-species relationship for the forest specialist and generalist birds [19].

Lastly, the species rarefaction and extrapolation curves for the Kwamsisi forest plateaued suggesting that further trapping efforts could have yielded insignificant additional species. The Kwamsisi forest is the smallest of all the patches studied; therefore it seems that sampling in this forest was exhaustive to the extent that more of the rare species were captured [36]. The positive slopes in rarefaction and extrapolation curves for the rest of the forests on the other hand are an implication that continued sampling could have yielded more species. These observations can also be linked to area-species relationship as stated in preceding paragraphs.

\section{Conclusion}

This study has highlighted the pattern in assemblage of understory birds among four coastal forests in northeastern Tanzania. The study also has highlighted the significance of some of the factors that are important in influencing assemblage of understory birds in these forests. The importance of forest size in the maintenance of species richness of the understory birds was especially emphasized. However, the ongoing forest destruction that is reducing forest size is likely to pose negative effects on the understory bird populations. This is so as there is a threshold in forest size beyond which some species might not tolerate [42].

Forest edges on the other hand seemed important in holding more species of habitat generalists. However, this should be treated with caution as it could be dangerous especially when generalist and specialist species come in contact with each other following the ongoing habitat destruction within the study area. This contact could be at the cost of the specialist species with possible local extinction in some of them due to competitive exclusion [38] and this is most likely in the Msubugwe forest as the effect of forest destruction is already vivid [15]. However, the fact that the MorisitaHorn Sample Similarity Indices of Msubugwe and Zaraninge forests were similar means that the negative impact of habitat degradation has not altered the species composition yet. Thus, there is still a chance of rescuing sensitive groups of birds such as insectivores from local extinction if habitat destruction is controlled [9].
Therefore, based on above concerns, the following are recommended:

(i) Strict control measures to stop illegal tree cutting especially in the Msubugwe forest should be effected by responsible authorities. When illegal activities are stopped, there is a chance of saving the understory birds as it is evident that species composition has not been severely altered since the Morisita-Horn Sample Similarity Indices of the highly disturbed Msubugwe forest and Zaraninge which is largely undisturbed were the highest.

(ii) Ongoing agricultural activities near the forests should be controlled to stop forest visitor and woodland/savannah birds from accessing forested habitats. Where it is not possible to control agriculture due to land rights, planting of native trees between the forests and areas affected by agriculture could be opted for. The trees could then act as buffer zones to stop generalist and/or woodland/savannah species from reaching interior parts of the forests.

(iii) Awareness raising campaign to local communities living in neighborhood of the forests on the importance of understory birds and forest conservation should be planned for as a way of minimizing uncontrolled human pressure on the forests' biodiversity.

\section{Competing Interests}

The authors declare that there is no conflict of interests regarding the publication of this paper.

\section{Acknowledgments}

This study was funded by SUA-VLIR Programme. Sokoine University of Agriculture through the Department of Wildlife Management is thanked for managing the funds and for the coordination of the study. The support of Tanzania National Parks (TANAPA) is highly appreciated for granting free entry permission to work in the Saadani National Park. Mr. Maneno is thanked for his assistance in bird trapping.

\section{References}

[1] W. D. Newmark, "A 16-year study of forest disturbance and understory bird community structure and composition in Tanzania," Conservation Biology, vol. 20, no. 1, pp. 122-134, 2006.

[2] N. M. Korfanta, W. D. Newmark, and M. J. Kauffman, "Longterm demographic consequences of habitat fragmentation to a tropical understory bird community," Ecology, vol. 93, no. 12, pp. 2548-2559, 2012.

[3] N. Arcilla, L. H. Holbech, and S. O'Donnell, "Severe declines of understory birds follow illegal logging in Upper Guinea forests of Ghana, West Africa," Biological Conservation, vol. 188, pp. 4149, 2015.

[4] N. J. Cordeiro and H. F. Howe, "Forest fragmentation severs mutualism between seed dispersers and an endemic African tree," Proceedings of the National Academy of Sciences of the United States of America, vol. 100, no. 2, pp. 14052-14056, 2003. 
[5] V. S. D. M. Gomes, J. Y. Tamashiro, and W. R. Silva, "Seed inflow to a forest patch promoted by understory frugivorous birds," Biota Neotropica, vol. 11, no. 4, pp. 95-102, 2011.

[6] Ç. H. Şekercioǧlu, G. C. Daily, and P. R. Ehrlich, "Ecosystem consequences of bird declines," Proceedings of the National Academy of Sciences of the United States of America, vol. 101, no. 52, pp. 18042-18047, 2004.

[7] S. G. W. Laurance, "Responses of understory rain forest birds to road edges in central Amazonia," Ecological Applications, vol. 14, no. 5, pp. 1344-1357, 2004.

[8] J. E. M. Watson, R. J. Whittaker, and T. P. Dawson, "Avifaunal responses to habitat fragmentation in the threatened littoral forests of south-eastern Madagascar," Journal of Biogeography, vol. 31, no. 11, pp. 1791-1807, 2004.

[9] D. Massimino, S. Masin, L. Bani, C. Dranzoa, and R. Massa, "Partial recovery of an african rainforest bird community 35 years after logging," Ethology Ecology and Evolution, vol. 20, no. 4, pp. 391-399, 2008.

[10] W. D. Newmark, "Tanzanian forest edge microclimatic gradients: dynamic patterns," Biotropica, vol. 33, no. 1, pp. 2-11, 2001.

[11] L. L. Powell, N. J. Cordeiro, and J. A. Stratford, "Ecology and conservation of avian insectivores of the rainforest understory: a pantropical perspective," Biological Conservation, vol. 188, pp. 1-10, 2015.

[12] D. M. Visco, N. L. Michel, W. A. Boyle, B. J. Sigel, S. Woltmann, and T. W. Sherry, "Patterns and causes of understory bird declines in human-disturbed tropical forest landscapes: a case study from Central America," Biological Conservation, vol. 191, pp. 117-129, 2015.

[13] W. D. Newmark, "Tropical forest fragmentation and the local extinction of understory birds in the Eastern Usambara Mountains, Tanzania," Conservation Biology, vol. 5, no. 1, pp. 67-78, 1991.

[14] R. Kumar and G. Shahabuddin, "Consequences of rural biomass extraction for bird communities in an Indian tropical dry forest and the role of vegetation structure," Conservation and Society, vol. 4, no. 4, pp. 562-591, 2006.

[15] S. N. Hassan, A. R. Salum, A. A. Rija, R. Modest, J. R. Kideghesho, and P. F. Malata, "Human-induced disturbances influence on bird communities of coastal forests in Eastern Tanzania," British Journal of Applied Science and Technology, vol. 3, no. 1, pp. 48-64, 2013.

[16] C. Werema, "Understorey bird abundance and diversity before and after a forest fire in Mangala forest reserve on the eastern slopes of the Uluguru mountains," Scopus, vol. 34, pp. 40-46, 2015.

[17] E. T. Azeria, I. Sanmartín, S. Ås, A. Carlson, and N. Burgess, "Biogeographic patterns of the East African coastal forest vertebrate fauna," Biodiversity and Conservation, vol. 16, no. 4, pp. 883-912, 2007.

[18] Conservation International, Biological Diversity in the Coastal Forests of Eastern Africa, 2008, http://www.eoearth.org/.

[19] R. B. Modest, S. N. Hassan, and A. A. Rija, "Spatial metrics effect of forest fragmentation on forest bird abundance and site occupancy probability: the influence of patch size and isolation," Ostrich, In press.

[20] M. W. Tobler, R. Cochard, and P. J. Edwards, "The impact of cattle ranching on large-scale vegetation patterns in a coastal savanna in Tanzania," Journal of Applied Ecology, vol. 40, no. 3, pp. 430-444, 2003.
[21] A. C. Treydte, P. J. Edwards, and W. Suter, "Shifts in native ungulate communities on a former cattle ranch in Tanzania," African Journal of Ecology, vol. 43, no. 4, pp. 302-311, 2005.

[22] N. D. Burgess, M. R. Huxham, C. O. F. Mlingwa, S. G. F. Davies, and C. J. Cutts, "Preliminary assessment of forest birds in Kiono, Pande, Kisiju and Kiwengoma coastal forests, Tanzania," Scopus, vol. 14, pp. 97-106, 1991.

[23] C. O. F. Mlingwa, "Breeding and moult cycles of the yellowbellied greenbul Chlorocichla flaviventris in coastal Tanzania," Scopus, vol. 20, pp. 29-32, 1988.

[24] N. D. Burgess, G. P. Clarke, and W. A. Rodgers, "Coastal forests of eastern Africa: status, endemism patterns and their potential causes," Biological Journal of the Linnean Society, vol. 64, no. 3, pp. 337-367, 1998.

[25] B. Leon and S. W. Nicolson, "Metabolic rate and body temperature of an African sunbird, Nectarinia chalybea: daily rhythm and the effect of ambient temperature," African Zoology, vol. 32, no. 2, pp. 31-36, 1997.

[26] J. V. Remsen Jr. and D. A. Good, "Misuse of data from mist-net captures to assess relative abundance in bird populations," Auk, vol. 113, no. 2, pp. 381-398, 1996.

[27] E. R. Buechley, Ç. H. Şekercioğlu, A. Atickem et al., "Importance of Ethiopian shade coffee farms for forest bird conservation," Biological Conservation, vol. 188, pp. 50-60, 2015.

[28] F. Gill and D. Donsker, Eds., IOC World Bird List (v 5.3), 2015.

[29] J. F. Clements, T. S. Schulenberg, M. J. Iliff et al., The eBird/Clements Checklist of Birds of the World: v2015, 2015.

[30] L. Bennun, C. Dranzoa, and D. Pomeroy, "The forest birds of Kenya and Uganda," Journal of East African Natural History, vol. 85, no. 1, pp. 23-48, 1996.

[31] E. Mlamba, A. Njoki, V. Otieno et al., Kitobo Forest Expedition: Avifaunal Survey of Kitobo Forest, South Eastern Kenya, 2013, http://www.africanbirdclub.org/.

[32] A. O. Owino, G. Amutete, R. K. Mulwa, and J. O. Oyugi, "Forest patch structures and bird species composition of a lowland riverine coastal forest in Kenya," Tropical Conservation Science, vol. 1, no. 3, pp. 242-264, 2008.

[33] T. Stevenson and J. Fanshawe, Field Guide to the Birds of East Africa: Kenya, Tanzania, Uganda, Rwanda, Burundi, T \& A. D. Poyser, London, UK, 2002.

[34] D. Bates, M. Mächler, B. Bolker, and S. Walker, "Fitting linear mixed-effects models using lme4," http://arxiv.org/abs/1406 .5823 .

[35] R. K. Colwell, EstimateS: Biodiversity Estimation Software, 2013.

[36] R. K. Colwell, A. Chao, N. J. Gotelli et al., "Models and estimators linking individual-based and sample-based rarefaction, extrapolation and comparison of assemblages," Journal of Plant Ecology, vol. 5, no. 1, pp. 3-21, 2012.

[37] J. W. Wilson, R. J. Van Aarde, and B. J. Van Rensburg, "Effects of habitat fragmentation on bird communities of sand forests in southern Mozambique," Ostrich, vol. 78, no. 1, pp. 37-42, 2007.

[38] J. D. Moll and J. S. Brown, "Competition and coexistence with multiple life-history stages," American Naturalist, vol. 171, no. 6, pp. 839-843, 2008.

[39] A. Uezu, J. P. Metzger, and J. M. E. Vielliard, "Effects of structural and functional connectivity and patch size on the abundance of seven Atlantic Forest bird species," Biological Conservation, vol. 123, no. 4, pp. 507-519, 2005.

[40] A. C. Martensen, M. C. Ribeiro, C. Banks-Leite, P. I. Prado, and J. P. Metzger, "Associations of forest cover, fragment area, and 
connectivity with neotropical understory bird species richness and abundance," Conservation Biology, vol. 26, no. 6, pp. 11001111, 2012.

[41] R. H. MacArthur and E. O. Wilson, The Theory of Island Biogeography, Princeton University Press, Princeton, NJ, USA, 1967.

[42] L. Fahrig, "How much habitat is enough?" Biological Conservation, vol. 100, no. 1, pp. 65-74, 2001. 

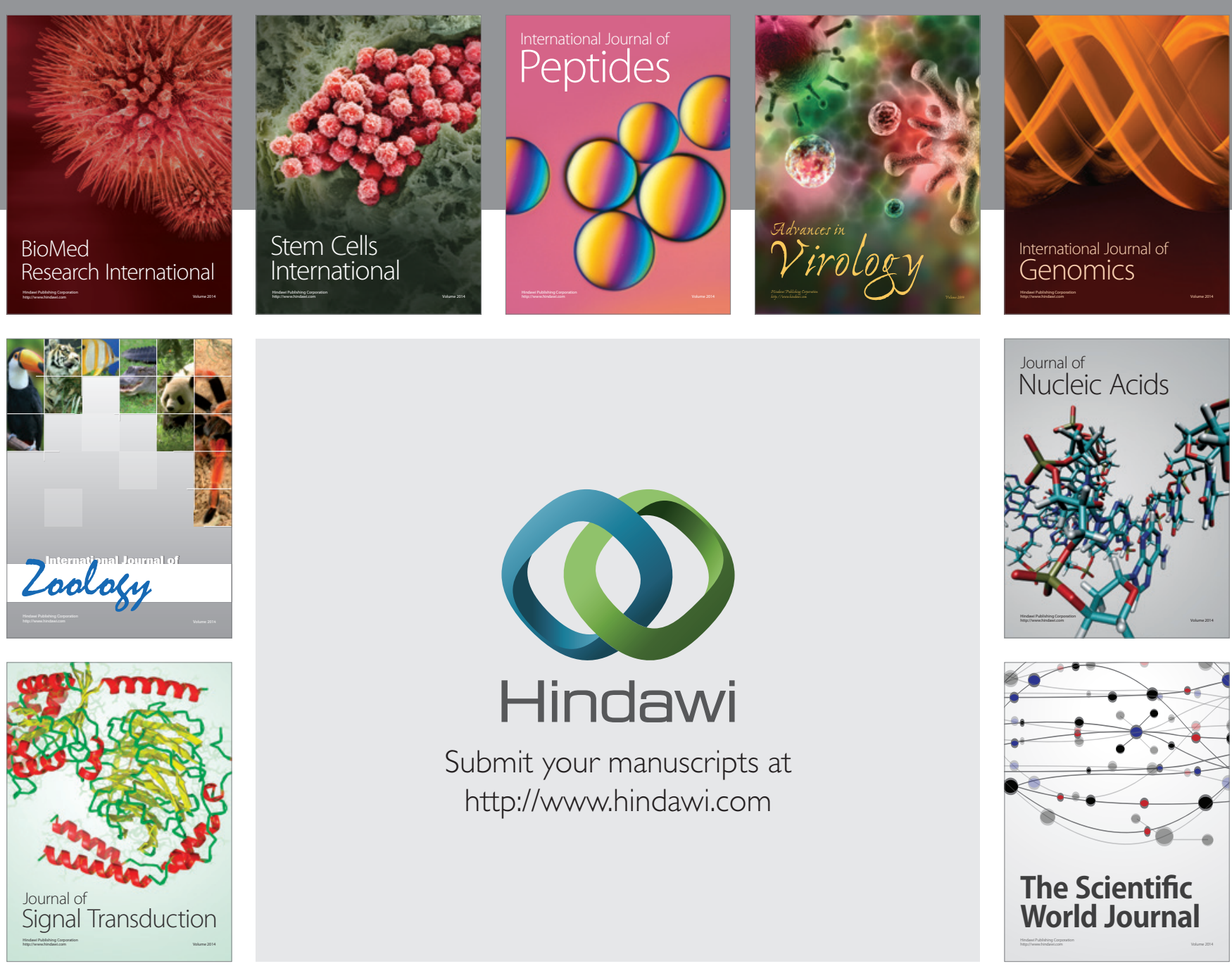

Submit your manuscripts at

http://www.hindawi.com
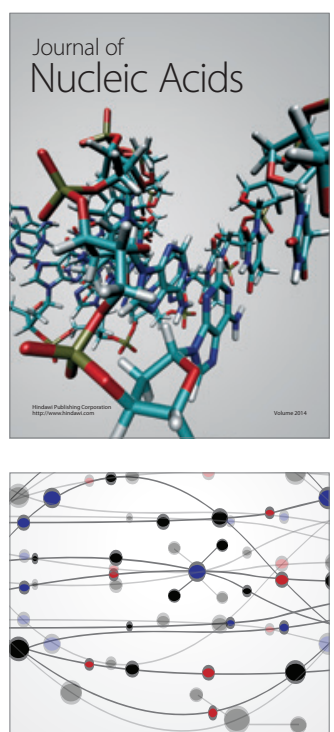

The Scientific World Journal
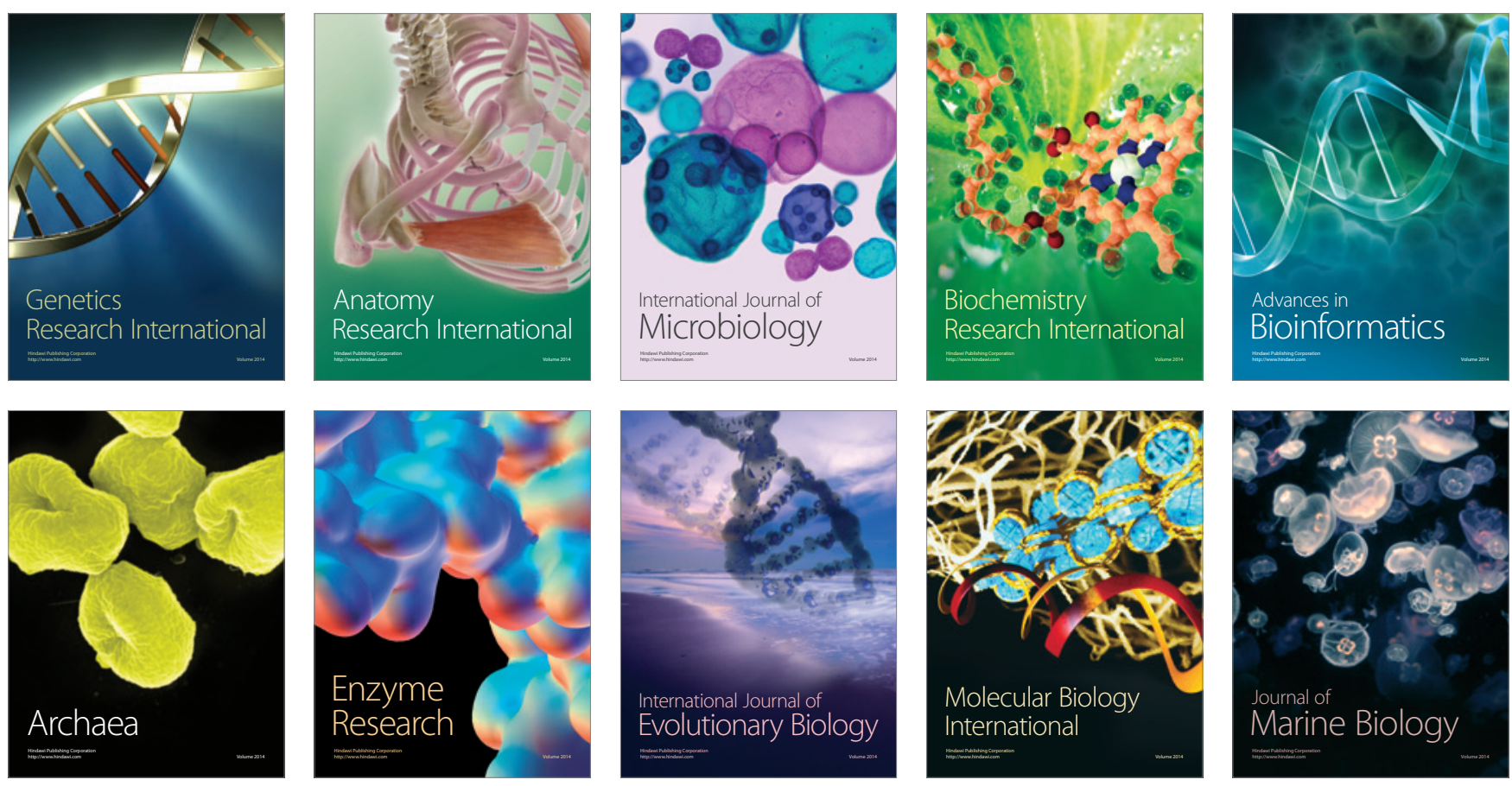